\title{
Physiological performance of wheat seeds treated with micronutrients and protection products during storage ${ }^{1}$
}

\author{
Joice Aline Freiberg ${ }^{2 *}$, Marcos Paulo Ludwig ${ }^{3}$, Suemar Alexandre Gonçalves \\ Avelar $^{4}$, Eduardo Girotto ${ }^{3}$, Darlan de Maria Eickstedt ${ }^{3}$, Rafael Rotta ${ }^{3}$
}

\begin{abstract}
Seeds with high quality are one of the important factors to consider in the crops establishment on field. Therefore, the physical and physiological quality of wheat seeds treated with mixes of micronutrients including zinc and protective products were aimed. The wheat seeds were analyzed in a factorial scheme $5 \times 3 \times 4$, with five storage time: $0,60,120,180$ and 240 days; three micronutrients: micronutrients $1(1 \% \mathrm{Mn} ; 0.1 \% \mathrm{Mo} ; 10 \% \mathrm{Zn})$; micronutrients $2(0.3 \% \mathrm{~B} ; 0.3 \% \mathrm{Co} ; 3 \% \mathrm{Zn})$ and no micronutrients, and four protective products: untreated seeds, polymer (Colorseed He), fungicide carboxin + thiram (Vitavax ${ }^{\circledR}$ Thiram 200 SC) + insecticide thiamethoxam (Cruiser $\left.{ }^{\circledR} 350 \mathrm{FS}\right)$ and polymer + fungicide + insecticide. After treatment, the seeds were stored under uncontrolled conditions for 240 days and at intervals of 60 days, the germination, accelerated aging and moisture content were determined. Wheat seeds untreated and treated with polymer have the best physiological performance during storage, regardless micronutrients treatments. The wheat seeds treated with carboxin + thiram + thiamethoxam and polymer + carboxin + thiram + thiamethoxam can be storage up to 120 days, under uncontrolled conditions, regardless micronutrients treatments. The seed treatment does not alter the moisture content of wheat seeds.
\end{abstract}

Index terms: Triticum aestivum L., coating, seeds treatment.

\section{Desempenho fisiológico de sementes de trigo tratadas com micronutrientes e produtos protetores durante o armazenamento}

\begin{abstract}
RESUMO - Sementes com alta qualidade são importantes no estabelecimento de culturas no campo. Portanto, objetivou-se avaliar a qualidade física e fisiológica de sementes de trigo tratadas com micronutrientes contendo zinco combinados a produtos protetores. As sementes foram analisadas em esquema fatorial 5x3x4, com cinco períodos de armazenamento: 0, 60, 120, 180 e 240 dias; três micronutrientes: micronutrientes $1(1 \% \mathrm{Mn} ; 0,1 \% \mathrm{Mo} ; 10 \% \mathrm{Zn})$; micronutrientes $2(0,3 \% \mathrm{~B} ; 0,3 \% \mathrm{Co} ; 3 \% \mathrm{Zn})$ e sem micronutrientes; e quatro produtos protetores: sementes não tratadas, polímero (Colorseed He), fungicida carboxina + tiram (Vitavax ${ }^{\circledR}$ Thiram 200 SC) + inseticida tiametoxam (Cruiser ${ }^{\circledR} 350$ FS) e polímero + fungicida + inseticida. Após o tratamento, as sementes foram armazenadas em condições não controladas por 240 dias e em intervalos de 60 dias determinou-se a germinação, envelhecimento acelerado e teor de umidade. Sementes não tratadas e tratadas com polímero têm o melhor desempenho fisiológico durante o armazenamento, independentemente dos tratamentos com micronutrientes. As sementes tratadas com carboxina + tiram + tiametoxam e polímero + carboxina + tiram + tiametoxam podem ser armazenadas até 120 dias, em condições não controladas, independentemente dos tratamentos com micronutrientes. $\mathrm{O}$ tratamento de sementes não altera o teor de umidade de sementes de trigo.
\end{abstract}

Termos para indexação: Triticum aestivum L., recobrimento, tratamento de sementes.

\section{Introduction}

The purpose of seed storage is to maintain seed quality at

Submitted on 03/10/2017. Accepted for publication on 04/28/2017. ${ }^{2}$ Departamento de Solos, UFSM, Caixa Postal 5082, 97105-100 - Santa Maria, RS, Brasil.

${ }^{3}$ Instituto Federal de Educação, Ciência e Tecnologia do Rio Grande do Sul, Caixa Postal 121, 98200-000 - Ibirubá, RS, Brasil. acceptable levels from the point of physiological maturity in the field till next sowing (Labbé and Villela, 2012; Carvalho and Nakagawa, 2012). During the storage period, seed quality

${ }^{4}$ Departmento de Horticultura, Cornell University, 14456, Geneva - New York, USA.

*Corresponding author <joice.freiberg@hotmail.com> 
may be affected mainly by seed moisture content besides environmental conditions, especially temperature and relative humidity, as well the presence of insects and microorganisms that consume seed reserves and reduce their physiological potential (Fessel et al., 2003).

Procedures such as seed treatment are used to improve seed performance and delay losses of vigor and viability during storage time. Seed protection can be achieved incorporating products as fungicides and insecticides (Bays et al., 2007) that reduce the potential transmission of pathogens by seeds, and protect the seeds from attack of fungus and insects during storage (Juliatti, 2010).

Moreover, growth regulators, micronutrients and biological agents may be used to obtain better seed and seedling performance and maximum crop genetic potential expression (Menten and Moraes, 2010). Additionally, the use of zinc has been associated with improvements in seed vigor and germination (Ribeiro and Santos, 1996), once this micronutrient acts as an enzymatic activator in lipids and proteins metabolic pathways (Prado et al., 2007). Furthermore, coat adding a polymer to form a thin layer on the seed surface allows better distribution of active ingredients (Baudet and Peres, 2004), reduce the amount of chemicals used (Karam et al., 2007) and minimize the leaching of these products from treated seeds (Avelar et al., 2012).

Pre-storage seed treatment shows up like an alternative to the adoption of technologies on wheat seed, but also, in some cases, it can harm the seed deterioration rate (Marcondes et al., 2011). In this regard, the quality of treated seeds has been evaluated for different crops, with positive or no responses obtained for different seed treatments. The association of fungicide carboxin + thiram with insecticide imidacloprid + thiodicarb reduced germination in wheat seeds cultivar BRS Gaivota (Abati et al., 2014). In maize, the treatment with insecticide thiamethoxam, at a dose of $1.4 \mathrm{~g}$. $\mathrm{kg}^{-1}$ of seeds, did not affected germination after 30 days of storage under non-control environmental conditions; however, seed vigor evaluated by cold test, reduced significantly in comparison to untreated seeds (Bittencourt et al., 2000). Already, wheat seed treatment with zinc sulfate, at dosages of $0,1,2,3$ and $4 \mathrm{~mL}$. $\mathrm{kg}^{-1}$ associated to fungicide $\left(3 \mathrm{~mL} . \mathrm{kg}^{-1}\right)$ and polymer $(0.8$ $\mathrm{mL} . \mathrm{kg}^{-1}$ ), did not affected seed viability even after six months of storage under non-controlled conditions (Tunes et al., 2012).

Considering the socio-economic importance of wheat as commodity (Cunha et al., 2011) and the possibility of using different chemical composition for seed treatment it is necessary studies that elucidate the physical and physiological performance of treated wheat seeds during storage time. Thus, it was aimed evaluate the physical and physiological quality of wheat seeds treated with different micronutrients, and combinations with polymer and fungicide + insecticide during storage for 240 days.

\section{Material and Methods}

The experiment was carried out at Seed and Grain Didactic and Research Laboratory of the Federal Institute of Education, Science and Technology of Rio Grande do Sul (IFRS - Campus Ibirubá) using wheat seeds, cultivar Tec Vigore, genetic category, grown during 2011/2011 season with $99 \%$ of initial germination and $100 \%$ physical purity.

The experimental design was completely randomized in a factorial scheme $5 \times 3 \times 4$, with five storage time $(0,60,120$, 180 and 240 days), three micronutrients and four protective products, with four replications.

The seeds were subject to three different treatments using mixes of micronutrients including zinc: micronutrients $1(1 \% \mathrm{Mn} ; 0.1 \% \mathrm{Mo} ; 10 \% \mathrm{Zn})$; micronutrients $2(0.3 \% \mathrm{~B}$; $0.3 \% \mathrm{Co} ; 3 \% \mathrm{Zn}$ ) and no micronutrients, and four protective products: untreated seeds, polymer (Colorseed He), fungicide carboxin + thiram (Vitavax ${ }^{\circledR}$ Thiram 200 SC) + insecticide thiamethoxam (Cruiser $\left.{ }^{\circledR} 350 \mathrm{FS}\right)$ and polymer + fungicide + insecticide (Table 1).

The application of the treatments occurred through the preparation of a solution using products dosages recommended by manufacturers: $1.5 \mathrm{~mL} . \mathrm{kg}^{-1} ; 1.2 \mathrm{~mL} . \mathrm{kg}^{-1} ; 2.5 \mathrm{~mL} . \mathrm{kg}^{-1}$ and $1.0 \mathrm{~mL} . \mathrm{kg}^{-1}$ for micronutrients, polymer, fungicide and insecticide, respectively. Water was added to the mixing solution to a maximum volume of $8 \mathrm{~mL} . \mathrm{kg}^{-1}$ of seeds and the seeds were treated using plastic bags of $2 \mathrm{~kg}$ capacity; adding the products to $0.3 \mathrm{~kg}$ of seeds and shaking them until the complete distribution of the products on the seed surface. Subsequently the seeds were dried in the shade then they were

Table 1. Description of combinations of micronutrients and protective products used in wheat seeds treatment.

\begin{tabular}{cl}
\hline Micronutrients & \multicolumn{1}{c}{ Protective products } \\
\hline \multirow{2}{*}{ Micronutrients1 } & Polymer \\
& $\begin{array}{l}\text { Fungicide }+ \text { insecticide } \\
\text { Polymer }+ \text { fungicide }+ \text { insecticide } \\
\text { Untreated seeds }\end{array}$ \\
\hline & Polymer \\
Micronutrients 2 & Fungicide + insecticide \\
& Polymer + fungicide + insecticide \\
& Untreated seeds \\
\hline & Polymer \\
& Fungicide + insecticide \\
Po micronutrients & Polymer + fungicide + insecticide \\
& Untreated seeds \\
\hline
\end{tabular}


transferred to paper bags and stored under non-controlled environmental conditions at Seed and Grain Didactic and Research Laboratory. The registers of relative humidity and temperature (Figure 1) were obtained from manual daily readings of Meteorological Station Ibirubá for the months from June to November/2012, and from Automatic Ibirubá Station - A883 for the months of December/2012 to February/2013 (INMET, 2013).

After treatment it was determined the seed moisture content and the physiological quality was evaluated by the following tests: germination, first count of germination and accelerated aging. The same tests were repeated at 60,120 , 180 and 240 days of storage, as procedure below:

Moisture content - the moisture content of the seeds was determined by the oven method at $105 \pm 3{ }^{\circ} \mathrm{C}$ (Brasil, 2009).

Germination - performed by four replicates of 50 seeds using Germitest ${ }^{\circledR}$ paper, soaked in distilled water until 2.5 times of the paper weight was achieved. The rolls were kept in a chamber at $20 \pm 2{ }^{\circ} \mathrm{C}$ for eight days, the germination was evaluated at eight days after sowing and the results expressed as percentage of normal seedlings according to the Rules for Seed Testing (Brasil, 2009).

First count of germination - it was accomplished together with the germination test, with counting carried on the fourth day after sowing (Brasil, 2009).

Accelerated aging - the seeds were uniformly distributed in a single layer, on a screen inside plastic boxes containing $40 \mathrm{~mL}$ of distilled water in the lower part. The boxes were maintained in an incubator B.O.D., adjusted to $43{ }^{\circ} \mathrm{C}$ for 48 hours (Fanan et al., 2006), then the germination was performed. The results were expressed as percentage of normal seedlings on the fourth day after sowing.

The data were submitted to variance analysis and hypothesis testing to verify the significance of the effect of time, micronutrient, protective products and interactions. When significant difference was found the means were fitted to a polynomial model using regression or compared by Tukey, according to the significance at the 0.05 level, using the statistical software Winstat.

\section{Results and Discussion}

There was no significant interaction for storage $\mathrm{x}$ micronutrients $\mathrm{x}$ protective products in any of the evaluated parameters (Table 2), which demonstrates that the micronutrients used did not affect the protective products during storage. On the other hand, there was significant interaction between storage $\mathrm{x}$ protective products in the germination and first count of germination evaluations, evidencing that the associations of the protective products can affect differently seed quality during storage. For accelerated aging, only the main effect of protective products was observed (Table 2). All parameters presented the main effect for storage.

The seed moisture content did not presented significant difference between the treatments. The moisture content, initially 13.7, showed a tendency to achieve hygroscopic equilibrium with the air of the storage site, fitting into a quadratic model (Figure 2). There was a reduction of $0.8 \%$ in the first 60 days of storage and a reduction of $0.3 \%$ in the following 60 days until 120 days when the seeds achieved hygroscopic equilibrium with the relative humidity between 60 and $70 \%$. After 120 days an increasing of the relative humidity average caused, once again, to seed moisture content a new hygroscopic equilibrium. This behavior is caused by water potential difference between seeds and storage environment in different air temperature and relative humidity

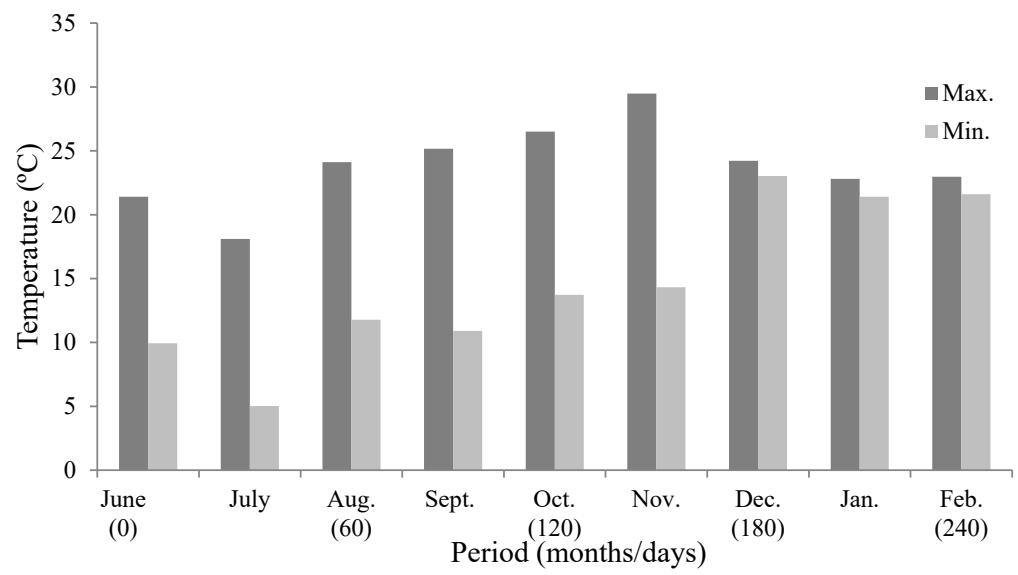

Figure 1. Average of maximum and minimum temperature $\left({ }^{\circ} \mathrm{C}\right)$ measured monthly after wheat seed treatment and stored under uncontrolled environmental conditions for 240 days. Ibirubá 2012-2013. 
Table 2. Variance analysis of moisture content (MC), germination (GERM), first count of germination (FCG) and accelerated aging (AA) in wheat seeds of cultivar Tec Vigore submitted to micronutrients and protective products and stored for 240 days.

\begin{tabular}{|c|c|c|c|c|c|}
\hline \multirow{2}{*}{ Source of variation } & \multirow{2}{*}{$\begin{array}{l}\text { Degree of } \\
\text { Freedom }\end{array}$} & \multicolumn{4}{|c|}{ Calculated F Value } \\
\hline & & $\mathrm{MC}$ & GERM & FCG & AA \\
\hline Storage $(\mathrm{S})^{1}$ & 4 & $88.43^{*}$ & $281.73^{*}$ & $653.19 *$ & $213.97 *$ \\
\hline Protective products $(\mathrm{PP})^{2}$ & 3 & 0.30 & $12.83 *$ & $36.81 *$ & $52.88^{*}$ \\
\hline Micronutrients (M) ${ }^{3}$ & 2 & 0.22 & 0.4 & 0.03 & 1.16 \\
\hline $\mathrm{S} \times \mathrm{PP}$ & 12 & 12.34 & $2.39 *$ & $2.82 *$ & 0.89 \\
\hline $\mathrm{M} \times \mathrm{PP}$ & 6 & 0.78 & 0.48 & 1.65 & 0.98 \\
\hline $\mathrm{S} \times \mathrm{M}$ & 8 & 12.25 & 0.52 & 1.37 & 0.21 \\
\hline $\mathrm{S} \times \mathrm{M} \times \mathrm{PP}$ & 24 & 0.50 & 0.32 & 0.53 & 0.46 \\
\hline Residue & 180 & - & - & - & - \\
\hline C.V. (\%) & & 3.4 & 4.0 & 5.2 & 16.0 \\
\hline
\end{tabular}

${ }^{1}$ Storage: 0, 60, 120,180 and 240 days after seed treatment.

${ }^{2}$ Protective products: untreated, polymer, fungicide + insecticide and polymer + fungicide + insecticide.

${ }^{3}$ Micronutrients: no micronutrients, micronutrients 1 and micronutrients 2.

$*$ p value $<0.01$

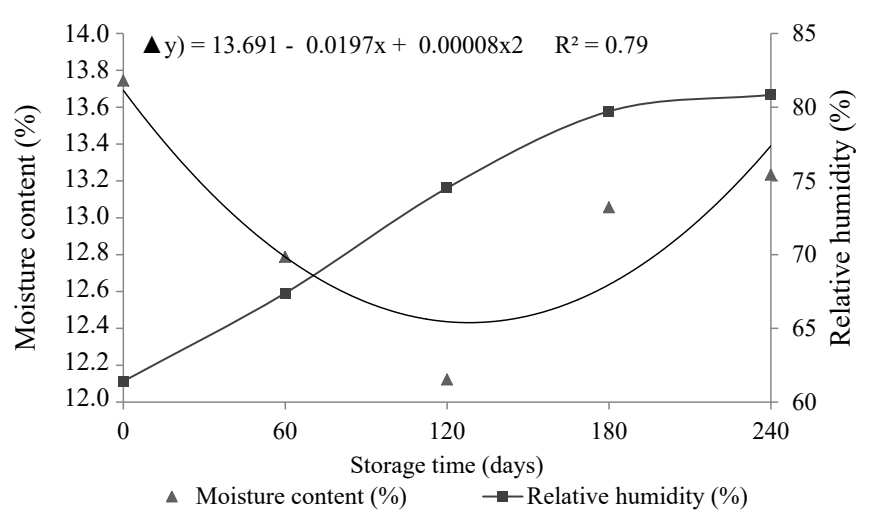

Figure 2. Relative humidity and moisture content of wheat seeds cultivar Tec Vigore after treatment with micronutrients and protective products at $0,60,120$, 180 and 240 days of storage.

(Marcos-Filho, 2005). In this study, the treated seeds stored under uncontrolled conditions of the environment, responded to the elevation of relative humidity. Similarly, Bittencourt et al. (2000) reported a moisture content reduction in maize seeds, as a function of the low relative humidity values during 30 days of storage with difference of $0.5 \%$ between thiamethoxam seed treatment and untreated seeds at first 15 days of storage. However, Tunes et al. (2016) observed that the moisture content of wheat seeds was not influenced by treatment with different doses of zinc sulfate $\left(\mathrm{ZnSO}_{4}\right)$ + fungicide (carboxin + thiram) + polymer applied using a syrup spray volume of $15 \mathrm{~mL} . \mathrm{kg}^{-1}$, and stored for six months under non-controlled environmental conditions.

In relation to seed germination (Table 3 and Figure 3), all treatments had germination above $90 \%$ until 120 days of storage, with the best results presented by the polymer and untreated seeds which remained above $95 \%$. After 180 days, treatment polymer + fungicide + insecticide $(85 \%)$ had a greater reduction in germination when compared to the treatments polymer, untreated seeds and fungicide + insecticide (90, 88 and $87 \%$, respectively). After 240 days of storage no treatments showed germination percentage above $80 \%$, with greater reductions observed in treatments polymer + insecticide + fungicide $(74 \%)$ and untreated seed $(74 \%)$. To first count of germination (Table 3 and Figure 4), all protective products resulted in percentage less than $90 \%$ at zero time. Untreated seeds and seeds treated with polymer showed the higher percentage of normal seedlings in the storage times evaluated. The treatments fungicide + insecticide and polymer + fungicide + insecticide reduced to 75 and $72 \%$ of normal seedlings at 180 days, and 55 and $49 \%$ to 240 days what was $10 \%$ lower than the treatments with better performance.

The results of germination and first count of germination showed that none of the used sources of micronutrients containing zinc was harmful to the seed quality during storage for up to 120 days. However, the treatments fungicide + insecticide and polymer + fungicide + insecticide showed phytotoxic effect, with lower percentage than both untreated and polymer coated seeds. To Tunes et al. (2012) wheat seeds treated with different doses of Zinc sulfate associated with fungicide, polymer and water to a solution volume of $12 \mathrm{~mL} . \mathrm{kg}^{-1}$ seed, did not reduce germination after treatment and storage for six months under uncontrolled conditions of air temperature and relative humidity. Matos et al. (2013) noted that hybrids corn seeds treated with carbendazim + 
Table 3. First count of germination and germination in wheat seeds of cultivar Tec Vigore submitted to micronutrients and protective products and stored for 240 days.

\begin{tabular}{|c|c|c|c|c|c|}
\hline \multirow{2}{*}{ Treatment } & \multicolumn{5}{|c|}{ Storage (days) } \\
\hline & 0 & 60 & 120 & 180 & 240 \\
\hline \multicolumn{6}{|c|}{ First count of germination } \\
\hline Untreated & $85 \mathrm{Aa}^{*}$ & $87 \mathrm{Aab}$ & $90 \mathrm{Aa}$ & $88 \mathrm{Aa}$ & $54 \mathrm{Bab}$ \\
\hline Polymer & $87 \mathrm{Aa}$ & $90 \mathrm{Aa}$ & $90 \mathrm{Aa}$ & $88 \mathrm{Aa}$ & $58 \mathrm{Ba}$ \\
\hline Fungicide + insecticide & $85 \mathrm{Aa}$ & $85 \mathrm{Abc}$ & $84 \mathrm{Ab}$ & $81 \mathrm{Ab}$ & $52 \mathrm{Bb}$ \\
\hline Polymer + fungicide + insecticide & $85 \mathrm{Aa}$ & $83 \mathrm{Ac}$ & $84 \mathrm{Ab}$ & $81 \mathrm{Ab}$ & $45 \mathrm{Bc}$ \\
\hline \multicolumn{6}{|c|}{ Germination } \\
\hline Untreated & $97 \mathrm{Aa}$ & $95 \mathrm{Aba}$ & $94 \mathrm{Aba}$ & $92 \mathrm{Bab}$ & $72 \mathrm{Cb}$ \\
\hline Polymer & $96 \mathrm{Aa}$ & $95 \mathrm{Aa}$ & $95 \mathrm{Aa}$ & $93 \mathrm{Aa}$ & $79 \mathrm{Ba}$ \\
\hline Fungicide + insecticide & $96 \mathrm{Aa}$ & $94 \mathrm{Aba}$ & $91 \mathrm{BCb}$ & $89 \mathrm{Cb}$ & $76 \mathrm{Dab}$ \\
\hline Polymer + fungicide + insecticide & $95 \mathrm{Aa}$ & $93 \mathrm{Aba}$ & $90 \mathrm{Bb}$ & $89 \mathrm{Bb}$ & $72 \mathrm{Cb}$ \\
\hline
\end{tabular}

*Means followed by the same capital letter on the rows or lower case on the columns are not significantly different (Tukey 0.05 level of significance).

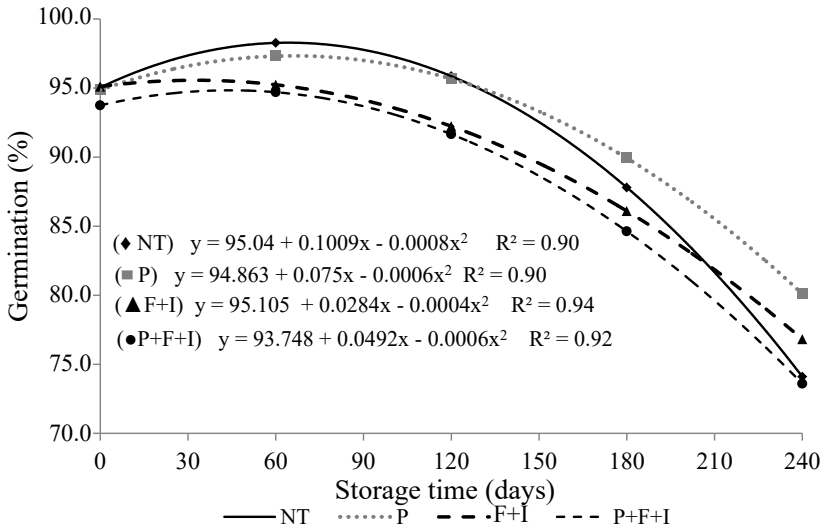

Figure 3. Wheat seed cultivar Tec Vigore germination after treatment with micronutrients and protective products at $0,60,120,180$ and 240 days of storage, (NT: untreated seeds; P: polymer; $\mathrm{F}+\mathrm{I}$ : fungicide + insecticide; $\mathrm{P}+\mathrm{F}+\mathrm{I}$ : polymer + fungicide + insecticide).

thiram + micronutrients $\left(100 \mathrm{~mL}\right.$ a.i. $100 \mathrm{~kg}^{-1}$ of seeds) had an increment on germination percentage when compared to nontreated seeds for all periods assessed during storage for six months. Simularly, Rufino et al. (2013) observed that wheat seeds, BRS Guamirim, treated with polymers or fungicides showed higher first count of germination than seeds without treatment, however, no significantly difference was verified in seeds treated with zinc or zinc + polymer. In the other hand, Marini et al. (2011) verified that wheat genotypes had different percentage of first count of germination and germination, with reductions of normal seedlings in seeds treated with fungicide Carboxin + Thiram, from $270 \mathrm{mg} . \mathrm{L}^{-1}$ dose.

The loss in seed physiological quality may be due to the interaction between either seeds or seedlings with the

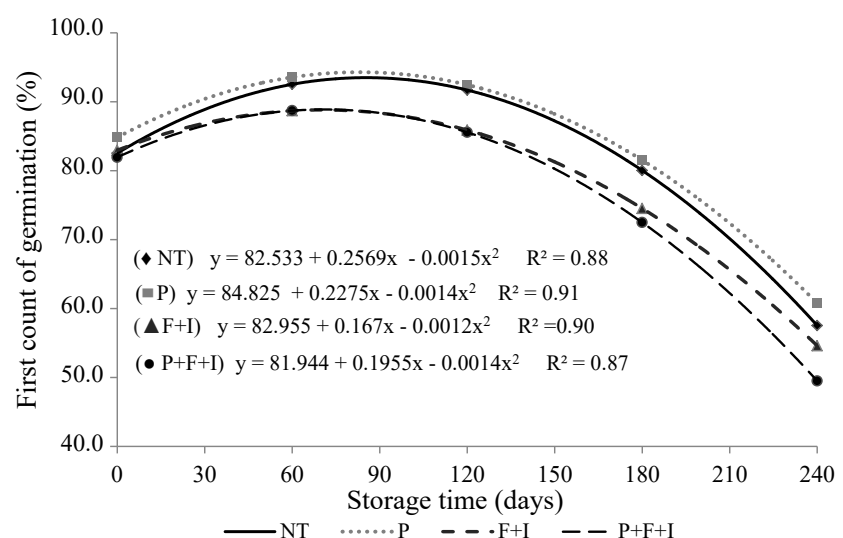

Figure 4. Wheat seed cultivar Tec Vigore first count of germination after treatment with micronutrients and protective products at $0,60,120,180$ and 240 days of storage (NT: untreated seeds; P: polymer; $\mathrm{F}+\mathrm{I}$ : fungicide + insecticide; $\mathrm{P}+\mathrm{F}+\mathrm{I}$ : polymer + fungicide + insecticide).

chemicals applied on the seed surface when germination test was performed using the paper towel substrate. In the same way, the addition of products by seed treatment can increase seed moisture. In this case, the higher seed moisture content and storage conditions, such as high temperature and relative humidity, potentiate seed deterioration (Marcos-Filho, 2005).

In relation to accelerated aging was observed a reduction rate of $10 \%$, in each three months of storage interval approximately (data not shown). Regardless of storage and micronutrient application, the treatment polymer and untreated seeds showed a better performance (13\% higher) compared to seeds treated with fungicide + insecticide and polymer + fungicide + insecticide (Figure 5) which contrast with Rufino et al. (2013) when they found that germination of wheat 
seeds treated with fungicide (Fludioxinil + Metalaxyl-M) after exposure to accelerated aging for 72 hours at $41^{\circ} \mathrm{C}$ was higher when compared to the treatments polymer, polymer + zinc and seeds without treatments. However, Fessel et al. (2003) observed reductions in vigor of corn seeds, evaluated by accelerated aging for 72 hours at $42{ }^{\circ} \mathrm{C}$ and using increasing dosages of fungicide and insecticide, mainly after twelve months of storage.

The reduction in viability and vigor is a natural process caused by aging of the seeds. Seed deterioration is an inevitable and irreversible process and the rate of deterioration during the storage time is influenced by seed moisture content, air relative humidity and temperature (Kapoor et al., 2011). The pronounced effect of deterioration of seeds, mainly after 180 days treatment, is related to the long period of exposure to adverse conditions of temperature and humidity. Furthermore, the effect phytotoxic of the products used in treat seed may also have reduced the seed viability. This effect was observed by Vanin et al. (2011) in sorghum seeds treated with different insecticides, with higher phytotoxicity caused by acephate than thiamethoxam and thiamethoxam + thiodicarb after 30 days of storage. According Tonin et al. (2014), the use of insecticide thiamethoxam, reduced vigor of corn seeds stored for 270 days in an environment with and without temperature and humidity control. Deuner et al. (2014) also observed greater reduction in vigor of corn seeds over the storage period for the treatments containing the insecticide thiamethoxam. In the same way, Silva et al. (2011) showed a marked reduction in the vigor and germination of treated rice seeds with fungicide carboxin + thiram and stored in hermetic packages for a period of 240 days. This effect corroborates with the results found for seed moisture content, germination and vigor, evidencing that the

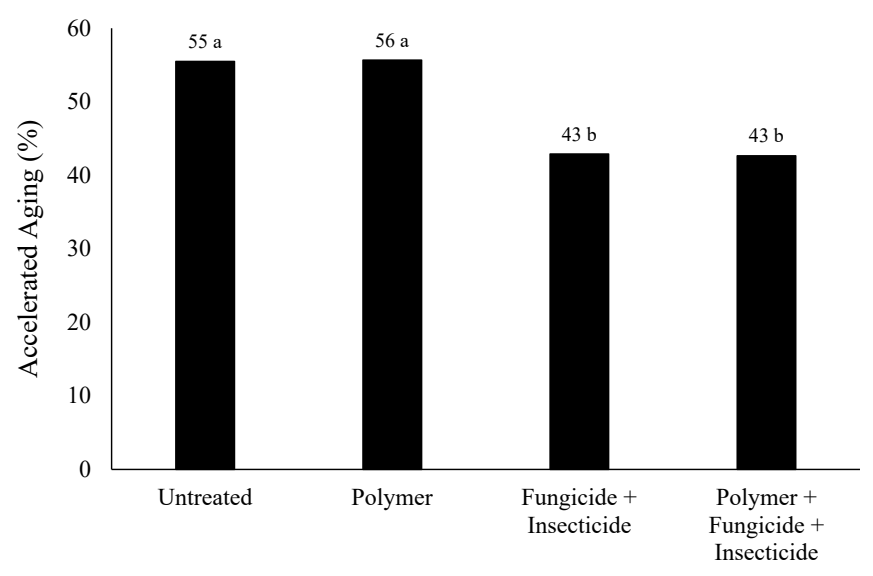

Figure 5. Wheat seed cultivar Tec Vigore accelerated aging after treatment with micronutrients and protective products at $0,60,120,180$ and 240 days of storage. *Means followed by the same letters do not differ ( $p$ value $\leq 0.05$ ) by the Tukey's test. reduction in seed viability was also associated with higher seed moisture content and chemical treatment.

In this sense, the use of high quality seeds allows high agronomic performance and it is fundamental for the crops establishment. In addition to the high quality, the incorporation of products through treatment and seed coating can improve their performance and allow the storage of wheat seeds without reducing their potential germination for up to 120 days.

\section{Conclusions}

Wheat seeds untreated and treated with polymer have the best physiological performance during storage, regardless micronutrients treatments.

The wheat seeds treaded with carboxin + thiram + thiamethoxam and polymer + carboxin + thiram + thiamethoxam can be storage up to 120 days, under uncontrolled conditions, regardless micronutrients treatments.

The seed treatments do not maintain seed quality for 240 days.

The seed treatment does not alter the moisture content of seeds.

\section{Acknowledgments}

To FAPERGS (Fundação de Amparo à Pesquisa do Estado do Rio Grande do Sul) for granting the scholarship to the first author.

\section{References}

ABATI, J.; ZUCARELI, C.; FOLONI, J.S.S; HENNING, F.A.; BRZEZINSKI, C.R.; HENNING, A.A. Treatment with fungicides and insecticides on the physiological quality and health of wheat seeds. Journal of Seed Science, v.36, n.4, p.392-398, 2014.http://www.scielo. $\mathrm{br} /$ scielo.php? script $=$ sci_arttext\&pid=S2317-15372014000400002

AVELAR, S.A.G.; SOUSA, F.V.; FISS, G.; BAUDET, L.; PESKE, S.T. The use of film coating on treated corn seed performance. Revista Brasileira de Sementes, v.34, n.2, p.186-192, 2012. http://www.scielo. br/scielo.php?script $=$ sci_arttext\&pid=S0101-31222012000200001

BAUDET, L.; PERES, W. Recobrimento de sementes. Seed News, v.8, n.1, p.20-23, 2004. http://www.seednews.inf.br/portugues/seed81/ artigocapa81.shtml

BAYS, R.; BAUDET, L.; HENNING, A.A.; LUCCA FILHO, O. Recobrimento de sementes de soja com micronutrientes, fungicida e polímero. Revista Brasileira de Sementes, v.29, n.2, p.60-67, 2007. http://www.scielo.br/scielo.php?script=sci_ arttext\&pid=S0101-31222007000200009

BITTENCOURT, S.R.M.; FERNANDES, M.A.; RIBEIRO, M.C.; VIEIRA, R.D. Desempenho de sementes de milho tratadas com inseticidas sistêmicos. Revista Brasileira de Sementes, v.22, n.2, p.86-93, 2000. http:// www.abrates.org.br/files/artigos/58984c51515df1.07068080_artigo12.pdf 
BRASIL. Ministério daAgricultura, PecuáriaeAbastecimento. Regras para análise de sementes. Ministério da Agricultura, Pecuária e Abastecimento. Secretaria de Defesa Agropecuária. Brasília: MAPA/ACS, 2009. 395p. http://www.agricultura.gov.br/arq_editor/ file/2946_regras_analise_sementes.pdf

CARVALHO, N.M.; NAKAGAWA, J. Sementes: ciência, tecnologia e produção. 5.ed. Jaboticabal: FUNEP, 2012. 590p.

CUNHA, G.R.; PIRES, J.L.F.; VARGAS, L. Bases para a produção competitiva e sustentável de trigo no Brasil. IN: CUNHA G.R.;PIRES, J.L.F.; VARGAS, L. (Ed.). Trigo no Brasil: bases para produção competitiva e sustentável. Passo Fundo: Embrapa Trigo, 2011, p.19-25.

DEUNER, C.; ROSA, K.C.; MENEGHELlO, G.E.; BORGES, C.T.; ALMEIDA, A.S.; BOHN, A. Physiological performance during storage of corn seed treated with insecticides and fungicide. Journal of Seed Science, v.36, n.2, p.204-212, 2014. http://www.scielo.br/ scielo.php?script $=$ sci_arttext\&pid=S2317-15372014000200009

FANAN, S.; MEDINA, P.F.; LIMA, T.C.; MARCOS-FILHO, J. Avaliação do vigor de sementes de trigo pelos testes de envelhecimento acelerado e de frio. Revista Brasileira de Sementes, v.28, n.2, p.152-158, 2006. http://www.scielo.br/scielo. php?script=sci_arttext\&pid=S0101-31222006000200021

FESSEL, S.A.; MENDONÇA, E.A.F.; CARVALHO, R.V.; VIEIRA, R.D. Efeito do tratamento químico sobre a conservação de sementes de milho durante o armazenamento. Revista Brasileira de Sementes, v.25, n.1, p.25-28, 2003. http://www.scielo.br/pdf/rbs/v25n1/19626.pdf

INMET. Instituto Nacional de Meteorologia. Estações automáticas. 2013. http://www.inmet.gov.br/portal/index. $\mathrm{php} ? \mathrm{r}=$ estacoes/estacoesAutomaticas

JULIATTI, F.C. Avanços no tratamento químico de sementes. Informativo Abrates, v.20, n.3, p.54-55, 2010. http://www.abrates. org.br/images/stories/informativos/v20n3/minicurso03.pdf

KAPOOR, N.; ARYA, A.; SIDDIQUI, M.A.; KUMAR, H.; AMIR, A. Physiological and biochemical changes during seed deterioration in aged seeds of rice (Oryza sativa L.). American Journal of Plant Physiology, v.6, n.1, p.28-35, 2011. http://scialert.net/qredirect. php?doi=ajpp.2011.28.35\&linkid=pdf

KARAM, D.; MAGALHÃES, P.C.; PADILHA, L. Efeito da adição de polímeros na viabilidade, no vigor e na longevidade de sementes de milho. Sete Lagoas-MG: Embrapa Milho e Sorgo, 2007, 6p. (Circular Técnica, no 94). http://www.cnpms.embrapa.br/ publicacoes/publica/2007/circular/Circ_94.pdf

LABBÉ, L.M.B.; VILLELA, F.A. Armazenamento de sementes. In: PESKE, S.T.; VILLELA, F.A.; MENEGHELLO, G.E. (Eds.) Sementes: fundamentos científicos e tecnológicos. Pelotas: Editora Universitária/UFPEL, 3ed. 2012. p.481-528.

MARCONDES, M.C.; ANDREOLI, C.; MIGLIORANZA, E. Viability equation to determine the longevity of fungicide-treated seeds of wheat stored in a conventional warehouse. Acta Scientiarum Agronomy, v.33, n.3, p.539-544, 2011.http://www.scielo.br/scielo.php?script=sci_arttext\&pid=S180786212011000300023\&lng=en\&nrm=iso\&tlng=en

MARCOS-FILHO, J. Fisiologia de sementes de plantas cultivadas. Piracicaba: FEALQ, 2005. 495p.
MARINI, N., TUNES, L.M.; SILVA, J.I.; MORAES, D.M.; OLIVIO, F.; CANTOS, A.A. Efeito do fungicida Carboxim Tiram na qualidade fisiológica de sementes de trigo (Triticum aestivum L.). Revista Brasileira de Ciências Agrárias, v.6, n.1, p.17-22, 2011. http://www.redalyc.org/articulo.oa?id=119018527003

MATOS, C.S.M.; BARROCAS, E.N.; MACHADO, J.C.; ALVES, F.C. Health and physiological quality of corn seeds treated with fungicides and assessed during storage. Journal of Seed Science, v.35, n.1, p.10-16, 2013. http://www.scielo.br/pdf/jss/v35n1/01.pdf

MENTEN, J.O.; MORAES, M.H.D. Tratamento de sementes: histórico, tipos, características e benefícios. Informativo Abrates, v.20, n.3, p.52-53, 2010. http://www.abrates.org.br/images/stories/ informativos/v20n3/minicurso03.pdf

PRADO, R.M.; NATALE, W.; MOURO, M.C. Fontes de zinco aplicado via semente na nutrição e crescimento inicial do milho cv. Fort. Bioscience Journal, v.23, n.2, p.16-24, 2007. http://www.seer. ufu.br/index.php/biosciencejournal/article/viewFile/6375/4117

RIBEIRO, N.D.; SANTOS, O.S. Aproveitamento do zinco aplicado na semente na nutrição da planta. Ciência Rural, v.26, n. 1, p.159-165, 1996. http://www.scielo.br/scielo.php?script=sci arttext\&pid=S0103-84781996000100030

RUFINO, C.A.; TAVARES, L.C.; BRUNES, A.P.; LEMES, E.S.; VILLELA, F.A. Treatment of wheat seed with zinc, fungicide, and polymer: seed quality and yield. Journal of Seed Science, v.35, n.1, p.106-112, 2013. http://www.scielo.br/scielo.php?script=sci arttext\&pid=S2317-15372013000100015

SILVA, C.S.; LUCCA FILHO, O.A.; ZIMMER, P.D.; BONINI FILHO, R.M. Efeito do tratamento químico sobre a qualidade fisiológica e sanitária de sementes de arroz com diferentes graus de umidade. Revista Brasileira de Sementes, v.33, n.3 p.426-434, 2011. http://www.scielo.br/scielo.php?script=sci arttext\&pid $=$ S010131222011000300005\&lng=pt\&nrm $=$ iso

TONIN, R.F.B.; LUCCA FILHO, O.A.; LABBE, L.M.B.; ROSSETTO, M. Potencial fisiológico de sementes de milho híbrido tratadas com inseticidas e armazenadas em duas condições de ambiente. Scientia Agropecuaria, v.5, n.1, p.0716, 2014. http://www.scielo.org.pe/scielo.php? script $=$ sci arttext\&pid $=$ S207799172014000100001\&lng=es\&nrm=iso

TUNES, L.M.; RODRIGUES, D.B.; GADOTTI, G.I.; ALMEIDA, A.S.; GEWEHR, E.; RADKE, A.K. Health and quality of zinc coated wheat seeds during storage. Bioscience Journal, v.32, n.1, p.140-149, 2016. http://www.seer.ufu.br/index.php/biosciencejournal/article/view/26249

TUNES, L.M.; PEDROSO, D.C.; TAVARES, L.C.; BARBIERI, A.P.P.; BARROS, A.C.S.A.; MUNIZ, M.F.B. Tratamento de sementes de trigo com zinco: armazenabilidade, componentes do rendimento e teor do elemento nas sementes. Ciência Rural, v.42, n.7, p.1141-1146, 2012. http://www.scielo.br/scielo.php?script=sci arttext\&pid=S0103-84782012000700001

VANIN, A.; SILVA, A.G.; FERNANDES, C.P.C.; FERREIRA, W.S.; RATTES, J.F. Tratamento de sementes de sorgo com inseticidas. Revista Brasileira de Sementes, v.33, n.2, p.299-309, 2011. http://www.scielo. br/scielo.php?script=sci_arttext\&pid=S0101-31222011000200012 